Thorax (1969), 24, 707.

\title{
Rheological assessment of mucolytic agents on sputum of chronic bronchitics
}

\author{
J. E. DIPPY ${ }^{1}$ AND S. S. DAVIS \\ From the Pharmacology Department, Guy's Hospital Medical School, London S.E.1, and the \\ School of Pharmacy, Pharmaceutics Department, London W.C.I
}

\begin{abstract}
In vitro and in vivo studies were made on the sputum of chronic bronchitics using a FerrantiShirley cone and plate viscometer and a new stress relaxation method. The latter utilized a modified chemical balance and permitted study at very low shear rates. The results from simpler apparatus correlated well with the data obtained with the cone and plate viscometer. Significant reduction in four chosen parameters of viscosity occurred in vitro with $N$-acetylcysteine and with ascorbic acid-hydrogen peroxide-cupric ion complex (A.A.H.Cu.), but not with 4-molar urea. In vivo studies showed that, using freshly prepared A.A.H.Cu in an efficient hospital nebulizer, a statistically significant reduction in the four viscosity parameters occurred with subjective ease of expectoration. Nebulization of A.A.H.Cu performed with a simpler domestic-type nebulizer did not produce satisfactory reduction of viscosity or ease of expectoration. Rheological methods previously employed to study mucus and mucolytic agent activity are briefly reviewed.
\end{abstract}

The difficulty of expectorating excessive thick mucus formed in the bronchial tree in chronic bronchitics needs no emphasis. During infected phases, the purulent, coloured sputum is less viscid and appropriate antibiotic treatment may return the secretion to a white mucoid consistency of great viscosity. White mucoid sputum of noninfected phases is chemically heterogeneous, with mucoproteins and mucopolysaccharides both represented. Chemical constituents of mucus have been the subject of further research in recent years (Brogan, 1959; Gernez-Rieux, Biserte, Havez, Voisin, Roussel, and Degand, 1966; Waldron-Edward and Skoryna, 1966). The diverse nature of mucolytic agents perhaps reflects this chemical heterogeneity. Agents studied in the past include detergents (Palmer, 1957), hyaluronidase (McClean and Hale, 1940), deoxyribonuclease (Armstrong and White, 1950), trypsin (Limber, Reiser, Roettig, and Curtis, 1952; Gernez-Rieux, Biserte, Havez, Voisin, Roussel, and Degand, 1964), chymotrypsin (Robinson, Woolley, and Altounyan, 1958), $N$-acetylcysteine (Webb, 1962 ; Sheffner, 1963 ; Sheffner, Medler, Jacobs, and Sarett, 1964 ; Hirsch and Kory, 1967) and related compounds, Martin, Causey, Sheffner, Wheeler and Corrigan, 1967), 4-molar urea (Waldron-Edward and Skoryna, 1966; Lieberman,

1Present address: Royal Gwent Hospital, Newport, Mon.
1967), ascorbic acid (Robertson, Ropes, and Bauer, 1941 ; Hale, 1944), and ascorbic acid-hydrogen peroxide-cupric ion system (Palmer, 1961).

Trypsin, chymotrypsin, and $N$-acetylcysteine have the disadvantages that they are expensive, and can be local irritants, giving bronchospasm and further wheezing (Bernstein and Ausdenmoore, 1964).

Although saturated urea solutions make many mucopolysaccharide systems more soluble, it has been found clinically that they have very little effect in reducing sputum viscosity, and furthermore an appreciable amount of urea may be absorbed into the blood-stream.

Of the remaining agents we have examined, the ascorbic acid-hydrogen peroxide-cupric ion system ('Ascoxal', Astra-Hewlett, referred to as A.A.H.Cu hereafter) has the advantages of being relatively innocuous when nebulized, nonirritant, and fairly cheap. This is a depolymerizing agent of muco-polysaccharide macromolecules.

The physical characteristics of sputum, obtained from patients suffering from chronic bronchitis, were examined by the Ferranti-Shirley cone and plate viscometer, and also by a new method which assesses stress relaxation [see glossary, p. 712]. The former instrument enables small amounts of non-ideal (or non-Newtonian) fluids [see glossary] to be studied for change in viscosity and elasticity under conditions of uni- 
formly changing shear rate. As such a method does not subject the sputum to forces comparable with those met in the bronchial tree, a new stress relaxation method has been introduced, whereby sputum elasticity is compared without subjecting it to strenuous forces.

The effect of the agents in vitro was determined by adding them to expectorated sputum, collected from bronchitic patients not being treated with mucolytic agents. The effect of nebulized A.A.H.Cu and water was then determined in patients by comparing sputum viscosity collected before and after nebulization treatment.

\section{MATERIALS AND METHODS}

\section{IN VITRO STUDIES}

Examination of sputum with the Ferranti-Shirley viscometer A general discussion of the underlying principles and operation of the Ferranti-Shirley viscometer (Fig. 1) is given by McKennell (1960).

One-millilitre aliquots of sputum were placed on the fixed plate and, after careful setting of the coneto-plate gap, the cone was made to revolve uni-

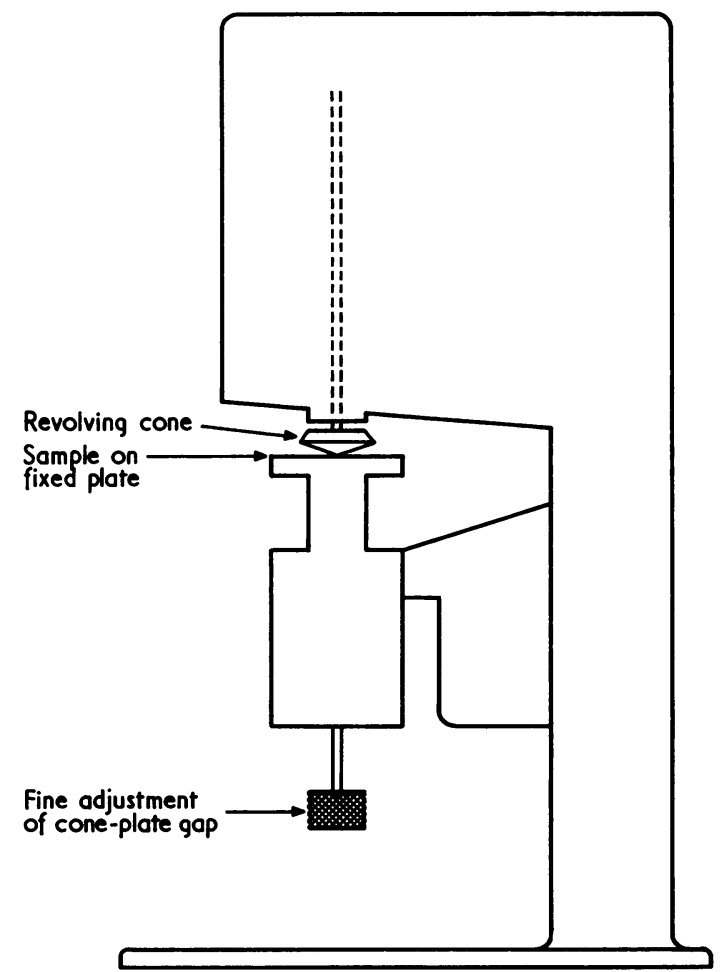

FIG. 1. Simplified diagram of a Ferranti-Shirley cone and plate viscometer.

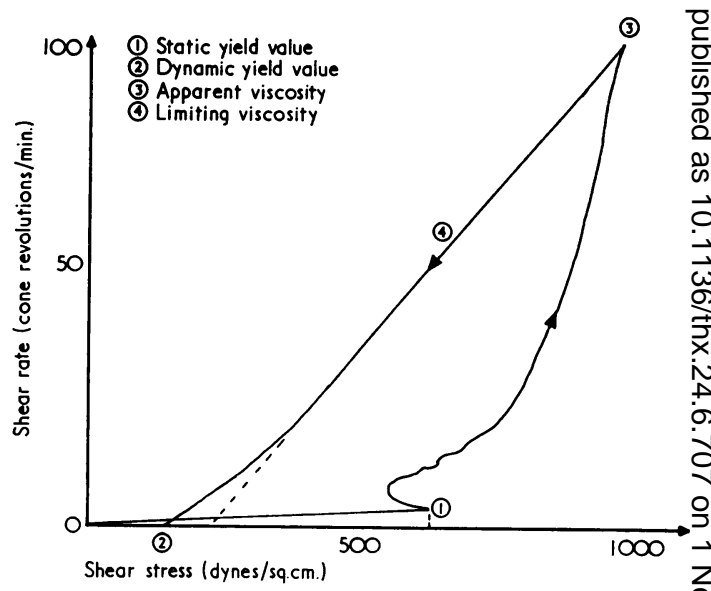

FIG. 2. Shear stress/shear rate relationship for mucoid sputum, obtained with the Ferranti-Shirley viscometer.

formly from rest to a maximum of 100 r.p.m. in 120 seconds. Having reached its maximum revolution the cone would then slow down uniformly over $\subseteq$ further 120 seconds, thus giving two lines on the graph (see Fig. 2). The choice of a total operatin time of 240 seconds represented a compromise whic took account of the difficulties introduced by inertio if the cone was accelerating and decelerating toof rapidly, and evaporation if the process was too slow?

Samples of sputum, as far as possible free of salivक्? were collected from chronic bronchitic patients in $\bar{x}$ non-infected stage (that is, when the sputum was mucoid), and studied within two hours of collection The patients were aged between 41 and 68 years, with a history of chronic bronchitis. All had daily coug and sputum production present for at least one yeañ as well as some emphysema (as evidenced by over expansion of the lungs and radiographic changes) an 9 asthma (i.e., paroxysms of wheezing).

Freezing and homogenization of sputum were nof performed so as to avoid breakdown of structure. Since at preliminary operating temperatures of $37^{\circ} \mathrm{C}$ 을 considerable thickening occurred due to evaporation all studies were performed at $25^{\circ} \mathrm{C} . \pm 0.1^{\circ} \mathrm{C}$., taking precautions with a water gasket to avoid evaporation A cone diameter of $70 \mathrm{~mm}$. and angle 0.0062 radians were found to be suitable for a sputum volume off $1.0 \mathrm{ml}$.

The alteration of shear stress with changing sheat rate (cone revolutions) for sputum is seen in Figure $\$$ The method provided four useful parametefo measured from the graph, viz., static and dynami yield values, and apparent and limiting viscosities [for definitions, see glossary].

The trace in Fig. 2, covering the entire time scale of 240 sec., shows that sputum viscosity is greatl\$ dependent on shear rate (no straight line relationship and that sputum molecules are broken down undef shear (viz., ascending and descending lines of the 
T A B L E I

CHANGES IN FOUR VISCOSITY PARAMETERS IN VITRO EFFECTED BY THE MUCOLYTIC AGENTS STUDIED

\begin{tabular}{|c|c|c|c|c|c|c|c|c|}
\hline \multicolumn{4}{|c|}{ Agent $^{1}$} & $\begin{array}{c}\text { Static Yield } \\
\text { Value }\end{array}$ & $\underset{\text { Value }}{\text { Dynamic Yield }}$ & $\begin{array}{l}\text { Apparent } \\
\text { Viscosity }\end{array}$ & $\begin{array}{l}\text { Limiting } \\
\text { Viscosity }\end{array}$ & $\begin{array}{c}\text { No. of } \\
\text { Experiments }\end{array}$ \\
\hline $\begin{array}{l}\text { Water } \\
\text { A.A.H.Cu } \\
\text { Acetylcysteine } \\
\text { A.A.H.Cu with } \\
\text { 0.005\% CuSO } \\
\text { 4-M urea }\end{array}$ & $\begin{array}{l}\ldots \\
\cdots \\
\ldots\end{array}$ & $\begin{array}{l}\ldots \\
\cdots \\
\ldots \\
\text { etate } \\
\ldots \\
\ldots\end{array}$ & $\begin{array}{l}\cdots \\
\cdots \\
\cdots \\
\cdots \\
\cdots\end{array}$ & $\begin{array}{c}73.8 \pm 14.8 \\
44.4 \pm 11.1 \\
0.01>\mathrm{P}>0.001 \\
46.9 \pm 10.1 \\
0.02>\mathrm{P}>0.01 \\
55.7 \pm 9.1 \\
80.4 \pm 13.2 \\
80.9 \pm 5.5\end{array}$ & $\begin{array}{c}75.0 \pm 12.6 \\
43.9 \pm 16.5 \\
0.01>\mathrm{P}>0.001 \\
41.4 \pm 15.9 \\
0.01>\mathrm{P}>0.001 \\
56.9 \pm 6.4 \\
85.9 \pm 23.7 \\
66.7 \pm 11.7\end{array}$ & $\begin{array}{c}77.9 \pm 12.4 \\
39.0 \pm 14.6 \\
0.01>\mathrm{P}=0.001 \\
37.4 \pm 8 \cdot 2 \\
0.01>\mathrm{P}>0.001 \\
63 \cdot 0 \pm 8 \cdot 0 \\
81.9 \pm 9 \cdot 2 \\
78.2 \pm 8.2\end{array}$ & $\begin{array}{c}77.2 \pm 12.6 \\
39.1 \pm 13.7 \\
0.01>\mathbf{P}>0.001 \\
45.6 \pm 10.1 \\
0.01>\mathrm{P}>0.001 \\
60.0 \pm 11.5 \\
80.3 \pm 10.0 \\
79.8 \pm 6.0\end{array}$ & $\begin{array}{r}10 \\
10 \\
6 \\
6 \\
4 \\
4 \\
4\end{array}$ \\
\hline
\end{tabular}

1 Contact time 20 minutes.

The results are expressed as a \% of original viscosity values, with standard deviations.
The 20 minutes.

graph are different, a steeper slope indicating 'thinner' sputum). This indicates the serious limitation of single point determinations. A second measurement on the same sample gave a straight line trace following the approximate course of the previous down curve, and even after three hours no return to the original loop occurred. This means that sputum was broken down irreversibly under shear, indicating the absence of thixotropic properties [see glossary].

In a series of experiments $4 \cdot 0-\mathrm{ml}$. samples of sputum were added with gentle mixing to $1.0 \mathrm{ml}$. of distilled water, or fresh A.A.H.Cu solution (75 mg. granules in $1 \mathrm{ml}$. water), or $20 \% N$-acetylcysteine, or 4 -molar urea, and 20 minutes later small portions were examined rheologically (Table I). In supplementary experiments the influence of contact time of $N$-acetylcysteine or A.A.H.Cu with sputum was investigated. The effects of the following factors on the four rheological parameters were also noted: (i) chelating the $\mathrm{Cu}++$ present in the preparation with excess sodium edetate, prior to mixing with sputum, and (ii) the sole introduction of $0.005 \%$ copper sulphate (Tables I and II).

\section{T A B L E II}

INFLUENCE OF CONTACT TIME IN VITRO ON VISCOSITY

\begin{tabular}{l|c|c|c|c}
\hline & \multicolumn{4}{|c}{ Contact Time (min.) } \\
\cline { 2 - 5 } Fresh Mucolytic Agent Used & 15 & 30 & 45 & 60 \\
\hline$N$-Acetylcysteine (20\% w/v) & $49 \cdot 0$ & $23 \cdot 5$ & $14 \cdot 9$ & $<1$ \\
A.A.H.Cu (100 mg./ml. water) & $72 \cdot 8$ & $30 \cdot 3$ & $28 \cdot 5$ & $26 \cdot 1$ \\
\hline
\end{tabular}

The means of the four chosen viscosity parameters are expressed as a $\%$ of the original means.

Examination of sputum by a stress relaxation method Four-millilitre samples of sputum were treated for 20 minutes in vitro with $1 \mathrm{ml}$. of water or fresh A.A.H.Cu (75 mg. granules per $\mathrm{ml}$. water) and placed in a glass container $(4 \times 2.5 \times 0.5 \mathrm{~cm}$.), into which was immersed a glass plate $(22 \times 10 \mathrm{~mm}$.) suspended from one arm of an electrical, damped balance (Fig. 3). The swing of the central pointer could be read off the scale at intervals of time, following the addition of $100 \mathrm{mg}$. to the other pan. The whole apparatus was housed in a temperature-controlled cabinet at $25^{\circ}$ C. The stress relaxation values (arbitrary units equivalent to the scale reading) at 60 seconds after the addition of the $100 \mathrm{mg}$. weight were found convenient for comparison.

The method afforded a simple comparative study on the effect of mucolytic agents on stress relaxation, a suitable parameter of elasticity [see glossary]. As the shear rates were very low, material was not broken down.

\section{IN VIVO NEBULIZATION STUDIES}

Ferranti-Shirley cone and plate viscometer Sputum samples were collected for three to hour hours from 10 subjects, before these patients were treated with (1) water or (2) A.A.H.Cu (75 mg. granules per $1 \mathrm{ml}$. water) for 20 minutes, using the Collison nebulizer apparatus. Sputum was then collected for a further 30 minutes, enabling a comparison of viscosity to be made of samples before and after treatment. A 30minute collecting period produced sufficient sputum volume to allow several recordings to be made, and ensured that the sputum collected did not just represent sputum well up the bronchial tree. Each patient received both treatments, but on different days.

A further series of six subjects was studied in a similar fashion where the patients inhaled one or other of the above agents for 20 minutes using a simple glass nebulizer.

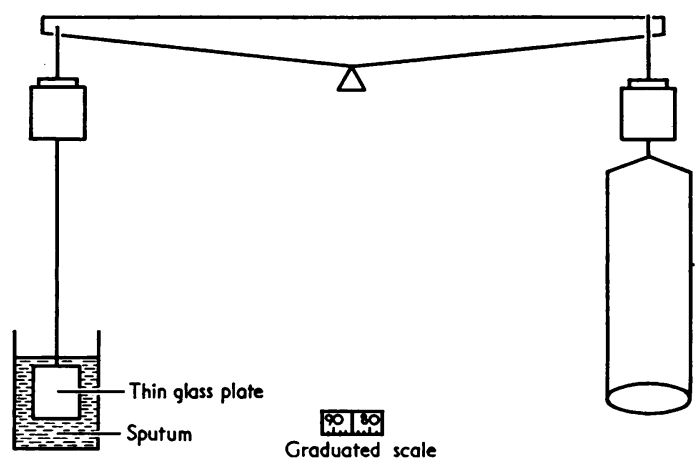

FIG. 3. Simplified diagram of the modified electrical damped balance used for the stress relaxation method. 


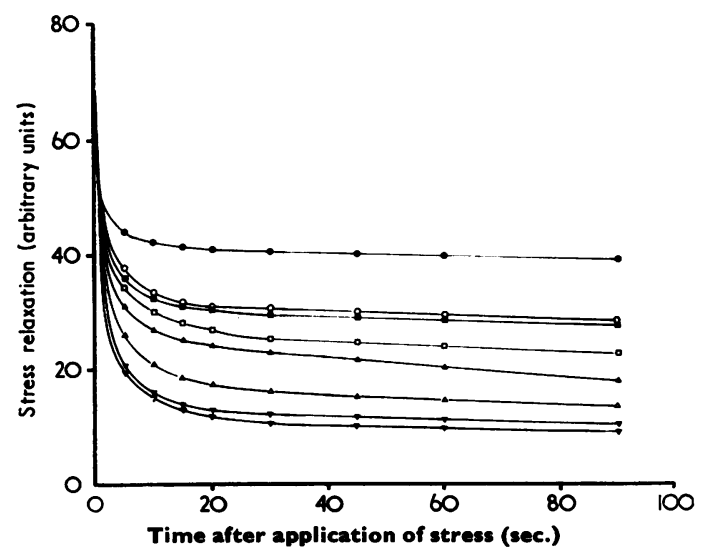

FIG. 4. Influence of contact time of A.A.H.Cu on stress relaxation of mucoid sputum: 1 undiluted sputum; sputum + water (control). Contact with A.A.H.Cu: 5 min., $\square 10$ min., $\Delta 15$ min., $\triangle 20$ min., $\nabla 30$ min., $\nabla 40$ $\min$.

Stress relaxation studies Similarly, sputum collected before and after nebulization treatment of the patient with water or A.A.H.Cu was examined by the simple method outlined earlier. Again each patient had both treatments, although on different days.

\section{RESULTS}

\section{IN VITRO WORK}

Studies using the Ferranti-Shirley cone and plate viscometer From Table I it will be seen that both $\mathrm{N}$-acetylcysteine and A.A.H.Cu reduced sputum viscosity greatly, but that chelation of $\mathrm{Cu}^{++}$impaired A.A.H.Cu mucolytic activity. By contrast, neither 4-molar urea nor $0.005 \%$ copper sulphate had mucolytic properties.

Table II shows that viscosity reduction was not an immediate process and that contact time should be defined.

Stress relaxation studies The effect on sputum stress relaxation of A.A.H.Cu and water in vitro, with time, is represented in Figure 4.

It will again be seen that mucolytic activity is not an instantaneous process, and therefore all readings have been made arbitrarily at 20 minutes. Table III compares stress relaxation values before and after treatment, in vitro, with A.A.H.Cu and water.

Significant reduction in muco-elastic properties, correlating with the cone and plate data, is shown.
IN VIVO WORK

Studies using the Ferranti-Shirley cone and plate viscometer

(a) Collison nebulizer method (Table IVf? Statistically significant reduction in all four paresmeters of viscosity occurred with A.A.H.Cu com pared with water.

All the patients experienced subjective ease $\vec{\phi}$ expectoration even after nebulization with wate but 8 out of 10 patients thought that the benefit was greater with the mucolytic agent.

(b) Simple hand-operated nebulizer methog (Table V): Although physical measuremento suggested some reduction in viscosity, whatever parameter was used, the changes were small and could well have been due to chance. This finding was supported by the patients' own impressione. Only two had a preference for the mucolytis agent, the remaining eight expressing no preference.

T A B L E I I I

COMPARISON OF STRESS RELAXATION VALUES of MUCOID SPUTUM, 60 SECONDS AFTER APPLICATION OF STRESS, WITH STANDARD DEVIATIONS, FOLLOWINE IN VITRO TREATMENT

\begin{tabular}{|c|c|c|c|c|}
\hline \multicolumn{4}{|c|}{ Agent ${ }^{1}$} & $\begin{array}{l}\text { Stress Relaxation at } 60 \text { Seconds } \\
\text { as } \% \text { of Pretreatment Value }\end{array}$ \\
\hline $\begin{array}{l}\text { A.A.H.Cu } \\
\text { Water }\end{array}$ & . & $\begin{array}{l}\cdots \\
\cdots\end{array}$ & 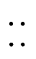 & $\begin{array}{l}45 \cdot 7 \pm 11 \cdot 1 \\
77 \cdot 5 \pm 12 \cdot 8\end{array}$ \\
\hline $\mathbf{P}$ & . & . & $\cdots$ & $\begin{array}{c}0.01>P>0.001 \\
(n=20)\end{array}$ \\
\hline
\end{tabular}

\section{T A B L E I V}

CHANGES IN THE FOUR VISCOSITY PARAMETERS, MEASURED BY FERRANTI-SHIRLEY VISCOMETER AFTEP NEBULIZATION WITH THE COLLISON APPARATUS

\begin{tabular}{|c|c|c|c|c|c|}
\hline $\begin{array}{c}\text { Mucolytic } \\
\text { Agent }\end{array}$ & $\begin{array}{l}\text { Static } \\
\text { Yield } \\
\text { Value }\end{array}$ & $\begin{array}{c}\text { Dynamic } \\
\text { Yield } \\
\text { Value }\end{array}$ & $\begin{array}{l}\text { Apparent } \\
\text { Viscosity }\end{array}$ & $\begin{array}{l}\text { Limiting } \\
\text { Viscosity }\end{array}$ & $\begin{array}{l}\text { N8 } \\
\text { of } \\
\text { Sub } \\
\text { jects }\end{array}$ \\
\hline $\begin{array}{l}\text { A.A.H.Cu } \\
\text { Water .. }\end{array}$ & $\begin{array}{l}66 \cdot 6 \pm 11.9 \\
78.7 \pm 11.4\end{array}$ & $\begin{array}{l}69 \cdot 7 \pm 11 \cdot 3 \\
82 \cdot 7 \pm 11 \cdot 0\end{array}$ & $\begin{array}{l}67.2 \pm 12.2 \\
78.8 \pm 8.3\end{array}$ & $\begin{array}{l}67 \cdot 3 \pm 12 \cdot 6 \\
79.8 \pm 10.7\end{array}$ & \\
\hline value & $0.05-0.02$ & $0.05-0.02$ & $0.05-0.02$ & $0.05-0.02$ & \\
\hline
\end{tabular}

The results in Tables IV and $V$ are expressed as a \% of origina viscosity values, with standard deviations.

T A B L E V

CHANGES IN THE FOUR VISCOSITY PARAMETERS MEASURED BY FERRANTI-SHIRIEY VISCOMETER AFT NEBULIZATION WITH A SIMPLE HAND-OPERATE

\begin{tabular}{|c|c|c|c|c|c|}
\hline $\begin{array}{c}\text { Mucolytic } \\
\text { Agent }\end{array}$ & $\begin{array}{l}\text { Static } \\
\text { Yield } \\
\text { Value }\end{array}$ & $\begin{array}{c}\text { Dynamic } \\
\text { Yield } \\
\text { Value }\end{array}$ & $\begin{array}{l}\text { Apparent } \\
\text { Viscosity }\end{array}$ & $\begin{array}{l}\text { Limiting } \\
\text { Viscosity }\end{array}$ & $\begin{array}{l}\text { Nod } \\
\text { of } \\
\text { Sub } \\
\text { ject }\end{array}$ \\
\hline $\begin{array}{l}\text { A.A.H.Cu } \\
\text { Water .. }\end{array}$ & $\begin{array}{l}87 \cdot 3 \pm 16 \cdot 4 \\
94 \cdot 9 \pm 7 \cdot 7\end{array}$ & $\begin{array}{l}94 \cdot 4 \pm 26 \cdot 1 \\
98.0 \pm 9.9\end{array}$ & $\begin{array}{l}87.2 \pm 15 \cdot 8 \\
93.0 \pm 14.8\end{array}$ & $\begin{array}{l}86 \cdot 1 \pm 16 \cdot 8 \\
88 \cdot 1 \pm 16 \cdot 5\end{array}$ & 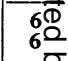 \\
\hline
\end{tabular}




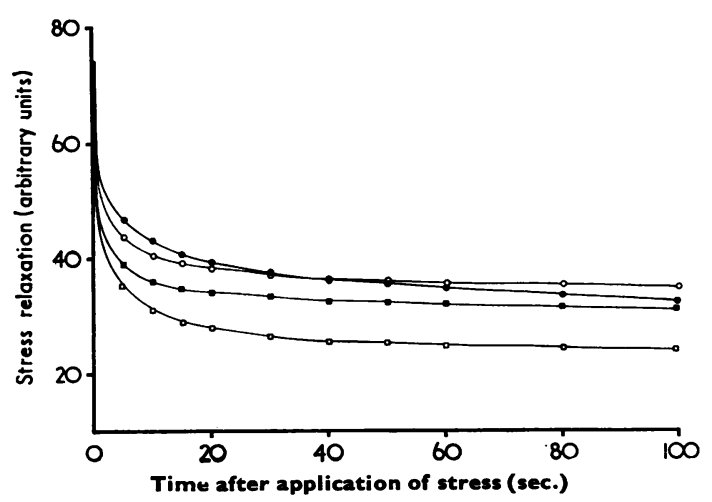

FIG. 5. Effect of nebulized A.A.H.Cu and water on stress relaxation of expectorated mucoid sputum in a patient. $\bigcirc$ prior to water nebulization. $\square$ after water nebulization. - prior to A.A.H.Cu nebulization. $\square$ after A.A.H.Cu nebulization.

Stress relaxation studies Figure 5 represents the reduction in stress relaxation of sputum, produced by Collison nebulized A.A.H.Cu and water in an individual patient.

The stress relaxation of the expectorated sputum was less after A.A.H.Cu nebulization than after water nebulization (Table VI).

\section{T A B L E V I}

COMPARISON OF STRESS RELAXATION VALUES OF MUCOID SPUTUM 60 SECONDS AFTER APPLICATION OF STRESS, WITH STANDARD DEVIATIONS FOLLOWING NEBULIZATION TREATMENT

\begin{tabular}{|c|c|c|c|}
\hline \multicolumn{3}{|c|}{ Agent $^{2}$} & $\begin{array}{l}\text { Stress Relaxation at } 60 \text { Seconds, } \\
\text { as } \% \text { of Pretreatment Values }\end{array}$ \\
\hline $\begin{array}{l}\text { A.A.H.Cu } \\
\text { Water }\end{array}$ & $\ldots$ & $\therefore$ & $\begin{array}{l}70 \cdot 8 \pm 9 \cdot 3 \\
83 \cdot 4 \pm 10 \cdot 4\end{array}$ \\
\hline $\mathbf{P}$ & . & . & $\begin{array}{c}0.05>P>0.02 \\
(n=12)\end{array}$ \\
\hline
\end{tabular}

1 Collison apparatus, over 20 minutes.

The reduction in sputum stress relaxation, although still statistically significant, is much less compared with the in vitro results.

\section{DISCUSSION}

The earliest studies on mucus viscosity employed methods based on Ostwald's capillary flow viscometer (Robertson, Ropes, and Bauer, 1940 ; McClean and Hale, 1941), a technique, however, which should be confined to simple fluids obeying the laws of physics, i.e., Ideal or Newtonian fluids. Usually, relative viscosity was measured against water. Later, viscometers based on timing the fall of a steel ball under gravity through mucus were used (Armstrong and White, 1950). These methods only give a single point value for viscosity, and do not take into account the fact that viscosity may alter with shear rate: we do not think that elasticity can be studied successfully by these means.

The method of determining the force required to push a perforated disc through a column of sputum was used by Elmes and White (1954), Hirsch, Kory, and Hamilton (1966), and Hirsch and Kory (1967). This enables static yield values to be obtained, i.e., minimum force required to produce flow.

Palmer (1957) made subjective and objective clinical studies of patients receiving nebulized water and detergent (Alevaire), sodium bicarbonate, and sodium chloride. The sputum was studied using a cone and plate viscometer, which reflected the deflection on to a circular scale for a given rotation speed. He concluded that the benefit to patients stemmed from rehydration of partly dried mucus. Later Palmer (1961) demonstrated the effects of A.A.H.Cu, in vitro and in vivo, again using a simple cone and plate viscometer with single point measurements of viscosity.

Mucolytic properties of $\mathrm{N}$-acetylcysteine were reported by Sheffner in 1963 and Sheffner et al. (1964) using a viscometer tube and a Brookfield rotational viscometer. The in vitro effects of various mucolytic agents, including cysteine, $N$ acetylcysteine, lysozyme, trypsin, and pronase, were studied by Gernez-Rieux et al. (1964) using rotational methods.

Carson, Goldhamer, and Weinberg (1966) studied properties of cat mucus by determining the velocity of steel balls, moving on through mucus in an electromagnetic field, generated from probes fixed at critical distances from the trachea. They also noted that if mucus was made too thin then cephalad flow was impaired, i.e., ciliary beating became ineffective.

The Ferranti-Shirley viscometer has been used to study mammalian mucus behaviour by Miller and Goldfarb (1965) in their preliminary studies prior to designing a simulated cilia apparatus using a vibrating spring.

In vitro studies on mucoid sputum from chronic bronchitics using (1) $20 \% \quad N$-acetylcysteine and (2) ascorbic acid-hydrogen peroxide$\mathrm{Cu}$ solution reduced the four chosen viscosity parameters (static yield value, dynamic yield value, apparent viscosity, and limiting viscosity) by at least half (see Table $I$ ). The reduction of viscosity obtained with 4 -molar urea or $0.005 \%$ copper sulphate solution, however, was not of statistical significance. 
As noted by previous workers, both the ascorbic acid-hydrogen peroxide- $\mathrm{Cu}^{++}$solution and $N$-acetylcysteine had to be used immediately on preparation to obtain best results. Complete chelation by sodium edetate of $\mathrm{Cu}^{++}$present in the preparation, before the addition of mucus, reduced in vitro mucolytic activity but did not abolish it. The catalytic influence of $\mathrm{Cu}^{++}$on ascorbic acid-induced biological reductions has been examined by Barron, DeMeio, and Klemperer (1936), Dekker and Dickinson (1940), Meiklejohn and Stewart (1941), and Matsumura and Pigman (1965).

Unlike Miller and Goldfarb (1965) we could not detect thixotropic properties in bronchial mucus (i.e., reversibility to original structure). Elmes and White (1954) also found no thixotropic behaviour.

The in vivo studies on chronic bronchitics using ascorbic acid-hydrogen peroxide- $\mathrm{Cu}^{++}$, nebulized by an efficient hospital nebulizer (Collison type), revealed a much smaller but useful reduction in the four viscosity parameters compared with the in vitro figures (see Table IV). All patients experienced some ease of expectoration even after the Collison-type nebulization with water, but 8 out of 10 patients thought that the benefit was greater with the mucolytic agent.

When using a simple hand-operated nebulizer no significant reduction in viscosity was obtained with ascorbic acid-hydrogen peroxide- $\mathrm{Cu}^{++}$or water, indicating unsatisfactory nebulization. Here, 2 out of 10 patients considered their expectoration to be easier with the mucolytic agent.

Complete loss of viscidity could render the passage of mucus by the bronchial cilia impossible, but insufficient viscosity reduction occurs with nebulization methods for this to be a risk, unless mucolytic agents are employed in bronchial lavage. A discussion and warning on this latter technique is given by Webb (1962).

The simple technique, involving a modified chemical balance, allows sputum to be examined rheologically in its natural state. Comparison of the stress relaxation values obtained correlate well with the results of the Ferranti-Shirley viscometer.

We are grateful for the co-operation of the consultant physicians and nursing and physiotherapy staff of Guy's Hospital, and to Professor E. Shotton and Mr. B. Warburton, of the School of Pharmacy, for helpful discussion.

We also thank Astro-Hewlett Ltd. for a supply of Ascoxal.

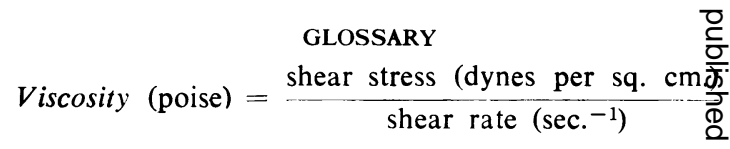

Relative viscosity The viscosity of a fluid expressef relative to water

Ideal (or Newtonian) Fluid A fluid obeying all the rules of physics. For such fluids the rate of sheat is in proportion to the applied stress. Most bioe logical fluids are Non-ideal (or Non-Newtoniant and there is no direct proportion between rate of shear and applied stress

Static yield value Minimum force (dynes per sq. $\mathrm{cm}$ required to cause flow

Dynamic yield value Minimum force (dynes peo sq. $\mathrm{cm}$.) required to cause flow after the shearing. process

Apparent viscosity Ratio of shear stress to shear rate at maximum shear rate, expressed in poise

Limiting viscosity Reciprocal of slope of linear por总 tion of the graph, expressed in poise

(limiting and apparent viscosity will be identicab for ideal fluids)

Stress relaxation $=\underset{\text { viscosity and elasticity }}{\text { A complexing }}$

(Muco)elasticity A muco-elastic material on bein made to flow has innate ability to resume ity previous position or shape

Thixotropic property Time-dependent, reversible los of consistency accompanying the application of shem

\section{REFERENCES}

Armstrong, J. B., and White, J. C. (1950). Liquefaction of viscotis purulent exudates by deoxyribonuclease. Lancet, $2,739$.

Barron, E. S. G., DeMeio, R. H., and Klemperer, F. (1936). Study biological oxidations. V. Copper and hemochromogens os catalysts for the oxidation of ascorbic acid. The mechanism of the oxidation. J. biol. Chem., 112, 625 .

Bernstein, I. L., and Ausdenmoore, R. W. (1964). Iatrogenic bronch spasm occurring during clinical trials of a new mucolytic agen? acetylcysteine. Dis. Chest, 46, 469.

Brogan, T. D. (1959). The carbohydrate complexes of bronchi secretion. Biochem. J., 71, 125.

Carson, S., Goldhamer, R., and Weinberg, M. S. (1966). Chara terization of physical, chemical and biological properties $\Theta$ mucus in the intact animal. Ann. N.Y. Acad. Sci., 130,935.

Dekker, A. O., and Dickinson, R. G. (1940). Oxidation of ascorb acid by oxygen with cupric ion as catalyst. J. Amer. chem. Sog. 62,2165 .

Elmes, P. C., and White, J. C. (1954). The rheological problem on chronic bronchitis. In Proc. 2nd Int. Congr. Rheol., Oxford 19593, p. 382 .

Gernez-Rieux, C., Biserte, G., Havez, R., Voisin, C., Roussel, Ro and Degand, $P$. (1964). Étude de l'activité 'in vitro' de differéntos agents réduisant la viscosité de l'expectoration. Acta tuber pneumol. belg., 55, 138.

(1966). Datos bioquimícos sobro el moco bronquial de la expectoración. Pren. méd. argent., 53, 426

Hale, C. W. (1944). Studies on diffusing factors. 4. The action \& reducing agents on hyaluronic acid and other polysaccharides reducing agents on hy
Biochem. J., 38, 362 .

Hirsch, S. R., and Kory, R. C. (1967). An evaluation of the effect of nebulized $\mathrm{N}$-acetylcysteine on sputum consistency. J. Allergy, $3 \Phi$ 265 .

- and Hamilton, L. H. (1966). Evaluation of changes sputum consistency with a new instrument. Amer. Rev. resp. Di\$, 94, 784.

Lieberman, J. (1967). In vitro evaluation of the mucolytic action $\mathbb{F}$ urea. J. Amer. med. Ass., 202, 694. 
Limber, C. R., Reiser, H. G., Roettig, L. C., and Curtis, G. M. (1952). Enzymatic lysis of respiratory secretions by aerosol trypsin. Ibid., $149,816$.

Martin, T. A., Causey, D. H., Sheffner, A. L., Wheeler, A. G., and Corrigan, J. R. (1967). Amides of $\mathrm{N}$-acetylcysteines as mucolytic agents. J. med. Chem., 10, 1172.

Matsumura, G., and Pigman, W. (1965). Catalytic role of copper and iron ions in the depolymerization of hyaluronic acid by ascorbic acid. Arch. Biochem., 110, 526.

McClean, D., and Hale, C. W. (1940). Mucinase and tissue permeability. Nature (Lond.), 145, 867

(1941). Studies on diffusing factors. The hyaluronidase activity of testicular extracts, bacterial culture filtrates and other activity of testicular extracts, bacterial culture filtrates and o.the
agents that increase tissue permeability. Biochem. J., 35, 159 .

McKennell, R. (1960). Measurement and control of viscosity and related flow properties. In The Instrument Manual., ed. Miller, J. T., 3rd ed., Section 11, p. 284 . United Trade Press, London.

Meiklejohn, G. T., and Stewart, C. P. (1941). Ascorbic acid oxidase from cucumber. Biochem. J., 35, 755.

Miller, C. E., and Goldfarb, H. (1965). An in vitro investigation of ciliated activity. Trans. Soc. Rheol., 9, pt 1, p. 135.

Palmer, K. N. V. (1957). The effect of an aerosol detergent in chronic bronchitis. Lancet, 1, 611.
- (1961). A ñw mucolytic agent by aerosol for inhalation in chronic bronchitis. Ibid., 2,802 .

Robertson, W. van B., Ropes, M. W., and Bauer, W. (1940). Mucinase a bacterial enzyme which hydrolyzes synovial fluid mucin and other mucins. J. biol. Chem., 133, 261.

- (1941). The degradation of mucins and polysaccharides by ascorbic acid and hydrogen peroxide. Biochem. J., 35, 903.

Robinson, W., Woolley, P. B., and Altounyan, R. E. C. (1958). Reduction of sputum viscosity in chronic bronchitis. Lancet, 2 , 819.

Sheffner, A. L. (1963). The reduction in vitro in viscosity of mucoprotein solutions by a new mucolytic agent, $N$-acetyl-L-cysteine. Ann. N.Y. Acad. Sci., 106, 298.

- Medler, E. M., Jacobs, L. W., and Sarett, H. P. (1964). The in vitro reduction in viscosity of human tracheo-bronchial secretions by acetylcysteine. Amer. Rev. resp. Dis., 90, 721.

Waldron-Edward, D., and Skoryna, S. C. (1966). The mucolytic activity of amides: a new approach to mucus dispersion. Can. med. Ass. J., 94, 1249.

Webb, W. R. (1962). Clinical evaluation of a new mucolytic agent, acetyl-cysteine. J. thorac. cardiovasc. Surg., 44, 330. 